\title{
Large day-to-day changes in extreme temperature in Poland and atmospheric circulation
}

\author{
Katarzyna Szyga-Pluta* \\ Department of Meteorology and Climatology, Adam Mickiewicz University in Poznań, ul. Krygowskiego 10, \\ 61-680 Poznań, Poland; pluta@amu.edu.pl \\ * Correspondence: pluta@amu.edu.pl
}

Received: date; Accepted: date; Published: date

\begin{abstract}
The primary purpose of the study was the determination of the spatial day-to-day variability of extreme temperatures in Poland and the dependency of large temperature changes on atmospheric circulation in accordance with the Grosswetterlagen (GWL) classification. The goal was implemented based on data from 1966 to 2015, made available by the Institute of Meteorology and Water Management - National Research Institute. Day-to-day changes in maximum and minimum temperatures were designated with a rate of $\geq 6{ }^{\circ} \mathrm{C}$ (large) and with a rate of $\geq 12{ }^{\circ} \mathrm{C}$ (very large) and their spatial distribution was presented. Finally, the analysis of the dependency of considerable temperature changes on atmospheric circulation in accordance with the Grosswetterlagen (GWL) classification was conducted. The obtained results showed that in Poland in the period 1966-2015 the number of large changes in both Tmax and Tmin slightly increased, although the fluctuations show spatial variability. Large changes in Tmax occur more frequently in spring, and in Tmin in winter. Large changes in Tmax and Tmin are mainly recorded during cyclonic circulation, however, the anticyclonic circulation types favour especially large decreases in Tmin.
\end{abstract}

Keywords: temperature extremes; day-to-day variability, large changes, circulation types; Grosswetterlagen, Poland

\section{Introduction}

Day-to-day temperature variability is of significance not only as an important characteristic of climate dynamics. It is also interesting from a practical point of view. Changes in mean daily temperature are on average lower than those in the case of extreme temperatures [1,2]. The decrease in the diurnal temperature range is approximately equal to the increase in mean temperature [3]. Knowledge of the probability and conditions of occurrence of considerable temperature changes are of particular importance. Substantial temperature fluctuations are unfavourable for the well-being of man, showing an irritating effect [4], and can have a negative impact on many areas of the economy, e.g.: rapid cooling in spring can cause freeze damage of plants, and rapid warming can lead to fast snowmelt resulting in flood threat $[4,6,7]$.

The observed contemporary climate warming is visible in the increase in the average global air temperature [8]. In the majority of cases, changes in mean daily temperature are relatively low, rarely interrupted with high temperature increases [9]. Together with climate change, the values of minimum and maximum temperatures also increase. This results in day-to-day variability of maximum and minimum temperatures. It is also worth emphasizing that variations in minimum temperatures are usually greater than those in maximum temperatures [10]. The variability of such changes in a year is probably uneven. Air temperature is largely generated by circulation factors $[9,11]$. High increases and decreases in extreme temperatures have been observed during air inflow from the north and west [12]. The greatest day-to-day changes in temperature are related to the North Atlantic Oscillation (NAO) [12]. Higher values of the NAO index are usually related not only to higher temperatures but also to lower day-to-day variability [10]. It was pointed out that extreme 
values of air temperature occur with anticyclonic circulation and strong highs blocking the zonal circulation, which in recent decades have been increasingly occurring over Europe, are of particular importance $[14,15,16]$.

Analyses of trends in the period 1880-1998 show that the variability of the spatial distribution of day-to-day temperature changes was subject to the following changes: a 5\% increase occurred in south-western Europe, a change of 0 to $-5 \%$ in the north-west, and a decrease by 5 to $10 \%$ in north-eastern Europe. Very large day-to-day changes in temperature are forecasted to occur increasingly frequently in summer [17]. The effects of climate change can depend more on the change in the minimum (Tmin) or maximum temperature (Tmax) than mean temperature [18]. Otherwise, the effect of precipitation deficit on an increase in extreme values of daily temperature amplitude has been observed [19].

Fewer studies in the climatological literature are devoted to the day-to-day variability of maximum and/or minimum temperature [e.g.:2,12,13,20-24] comparing to the number of studies concerning the mean temperature interdiurnal variations (ITV) or diurnal temperature range (DTR) [e.g.:7,10,17,25,26,27]. Additionally, the occurrence and changes of extreme air temperature values should be discussed in the context of circulation conditions because atmospheric circulation is considered one of the most important factors influencing weather and climate conditions in moderate latitudes [28,29].

Bearing the aforementioned in mind, the main objective of the research was the determination of the spatial day-to-day variability of extreme temperatures in Poland and its circulation conditions. The implementation of the primary study objective covers the determination of the spatial and multiannual variability of changes in extreme temperature: maximum (Tmax) and minimum (Tmin) from day to day in the period 1966-2015, and the designation of cases of large $\left(\geq 6^{\circ} \mathrm{C}\right)$ and very large $\left(\geq 12{ }^{\circ} \mathrm{C}\right)$ increases and decreases in extreme temperatures in particular months, years, and throughout the multiannual period. Particular attention was paid to the analysis of the impact of atmospheric circulation on the occurrence of large changes in extreme temperature (Tmax and Tmin).

\section{Materials and Methods}

The paper employed meteorological data from 18 stations in Poland (Figure 1, Table 1) belonging to the observation network of the Institute of Meteorology and Water Management National Research Institute (IMGW-PIB) except for mountain areas. The analysis covered the period 1966-2015.

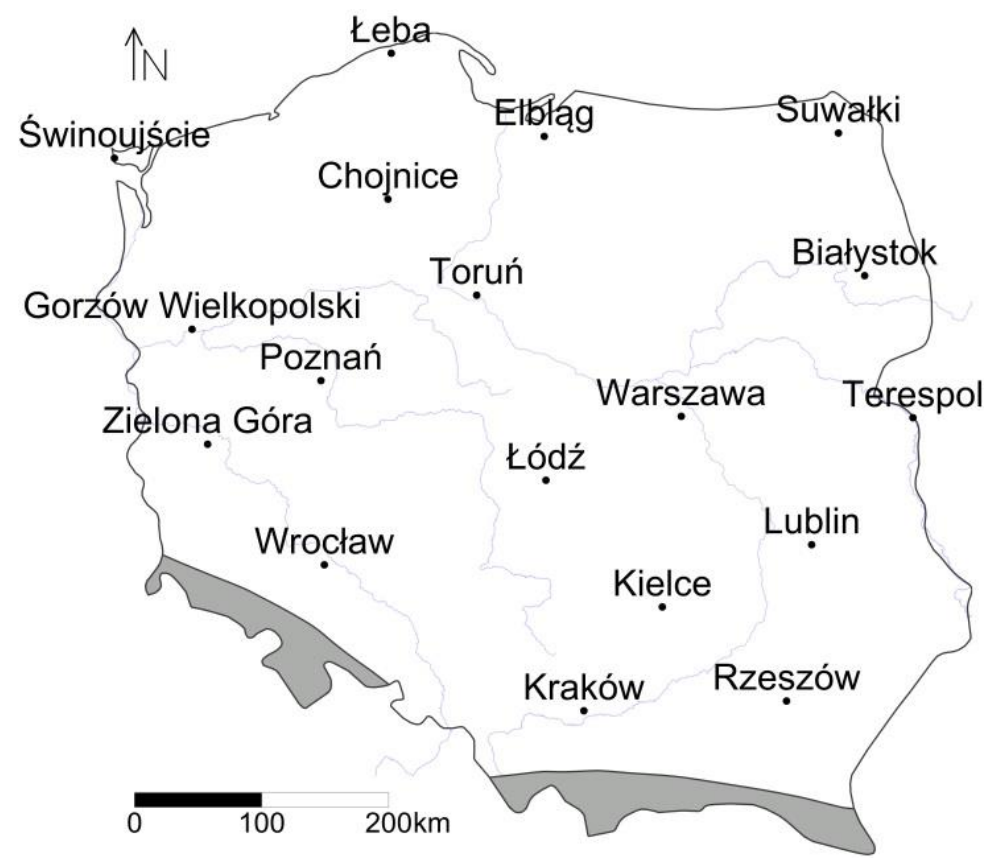

Figure 1. Locations of the analysed stations in Poland. 
Table 1. Geographical coordinates and altitude of selected stations.

\begin{tabular}{l|llc}
\hline Station & \multicolumn{1}{|c}{$\begin{array}{c}\Lambda \\
{[\mathrm{N}]}\end{array}$} & {$[\mathrm{E}]$} & $\mathrm{H}$ \\
\hline Białystok & 53.1074 & 23.1625 & 151 \\
\hline Chojnice & 53.7153 & 17.5325 & 172 \\
\hline Elbląg & 54.2231 & 19.5431 & 185 \\
\hline Gorzów Wielkopolski & 52.7411 & 15.2772 & 73 \\
\hline Kielce & 50.8103 & 20.6922 & 261 \\
\hline Kraków & 50.0803 & 19.8019 & 237 \\
\hline Lublin & 51.2167 & 22.3931 & 240 \\
\hline Łeba & 54.7536 & 17.5347 & 6 \\
\hline Łódź & 51.7233 & 19.3994 & 184 \\
\hline Poznań & 52.4210 & 16.8263 & 84 \\
\hline Rzeszów & 50.1100 & 22.0190 & 201 \\
\hline Suwałki & 54.1308 & 22.9489 & 186 \\
\hline Świnoujście & 53.9229 & 14.2410 & 5 \\
\hline Terespol & 52.0786 & 23.6219 & 137 \\
\hline Toruń & 53.0422 & 18.5953 & 72 \\
\hline Warszawa & 52.1658 & 20.9671 & 106 \\
\hline Wrocław & 51.1027 & 16.8858 & 124 \\
\hline Zielona Góra & 52.1402 & 15.7970 & \\
\hline & & & 52 \\
\hline
\end{tabular}

The calculations were based on daily values of maximum and minimum air temperature. A day-to-day change in maximum temperature $(\Delta \operatorname{Tmax})$ was calculated as the difference of maximum temperature on a given day and the preceding day. A day-to-day change in minimum temperature was determined analogically ( $\Delta \mathrm{Tmin})$. Day-to-day changes in maximum and minimum temperatures were designated with a rate of $\geq 6^{\circ} \mathrm{C}$, in the paper described as large, and these with a rate of $\geq 12{ }^{\circ} \mathrm{C}$, described as very large. Day-to-day changes in temperature of more than $6{ }^{\circ} \mathrm{C}$ have an irritating effect on the human organism (classification by Bajbakova et al. [4]), and changes of more than $12{ }^{\circ} \mathrm{C}$ are described as severe [4]. The number of positive and negative changes were determined for $\operatorname{Tmax}(\Delta \operatorname{Tmax} \uparrow, \Delta \operatorname{Tmax} \downarrow)$ and $\operatorname{Tmin}(\Delta \operatorname{Tmin} \uparrow, \Delta \operatorname{Tmin} \downarrow)$, as well as their occurrence in particular months and years in the analysed period. Trends of multiannual changes in temperature increases and decreases were determined, as well as their statistical significance. The determination of the trend of values averaged for the territory of Poland employed a 5-day moving average. The statistical assessment of changes applied a nonparametric Mann-Kendall test, and their statistical significance was assessed by means of the Sen method [30]. The spatial distribution of large changes in extreme temperatures was presented in maps. The next stage involved the analysis of the dependency of considerable temperature changes on the atmospheric circulation in accordance with the Grosswetterlagen (GWL) classification [31,32,33] (Table 2). To eliminate individual cases occurring in the few stations, only these cases were analysed when large changes in extreme air temperature values occurred at least in $20 \%$ of the stations. The frequency of occurrence of GWL circulation types in the years 1966-2015 was calculated, as well as the probability of occurrence of large day-to-day changes in Tmax and Tmin in particular circulation types. 
Table 2. Grosswetterlagen Classification [31,32,33].

\begin{tabular}{|c|c|c|}
\hline Grosswettertype (GWT) & Symbol & Grosswetterlage (GWL) \\
\hline North & $\begin{array}{l}\text { HB } \\
\text { HNA } \\
\text { HNZ } \\
\text { NA } \\
\text { NZ } \\
\text { TRM }\end{array}$ & $\begin{array}{c}\text { British Isles High } \\
\text { Norwegian Sea High, anticyclonic } \\
\text { Norwegian Sea High, cyclonic } \\
\text { North Circulation, anticyclonic } \\
\text { North Circulation, cyclonic } \\
\text { Central Europe Trough }\end{array}$ \\
\hline Northeast & $\begin{array}{l}\text { NEA } \\
\text { NEZ }\end{array}$ & $\begin{array}{c}\text { Northeast Circulation, anticyclonic } \\
\text { Northeast Circulation, cyclonic }\end{array}$ \\
\hline East & $\begin{array}{l}\text { HFA } \\
\text { HFZ } \\
\text { HNFA } \\
\text { HNFZ }\end{array}$ & $\begin{array}{c}\text { Fennoscandian High, anticyclonic } \\
\text { Fennoscandian High, cyclonic } \\
\text { Norwegian Sea/Fennoscandia High, anticyclonic } \\
\text { Norwegian Sea/Fennoscandia High, cyclonic }\end{array}$ \\
\hline Southeast & $\begin{array}{l}\text { SEA } \\
\text { SEZ }\end{array}$ & $\begin{array}{l}\text { Southeast Circulation, anticyclonic } \\
\text { Southeast Circulation, cyclonic }\end{array}$ \\
\hline South & $\begin{array}{l}\text { SA } \\
\text { SZ } \\
\text { TB } \\
\text { TRW }\end{array}$ & $\begin{array}{l}\text { South Circulation, anticyclonic } \\
\text { South Circulation, cyclonic } \\
\text { British Isles Low } \\
\text { Western Europe Trough }\end{array}$ \\
\hline Southwest & $\begin{array}{l}\text { SWA } \\
\text { SWZ }\end{array}$ & $\begin{array}{l}\text { Southwest Circulation, anticyclonic } \\
\text { Southwest Circulation, cyclonic }\end{array}$ \\
\hline West & $\begin{array}{l}\text { WA } \\
\text { WS } \\
\text { WZ } \\
\text { WW }\end{array}$ & $\begin{array}{l}\text { West Circulation, anticyclonic } \\
\text { West Circulation, cyclonic } \\
\text { Southern West Circulation } \\
\text { Angled West Circulation }\end{array}$ \\
\hline Northwest & $\begin{array}{l}\text { NWA } \\
\text { NWZ }\end{array}$ & $\begin{array}{l}\text { Northwest Circulation, anticyclonic } \\
\text { Northwest Circulation, cyclonic }\end{array}$ \\
\hline Central Europe High & $\begin{array}{l}\mathrm{HM} \\
\mathrm{BM}\end{array}$ & $\begin{array}{l}\text { Central European High } \\
\text { Central European Ridge }\end{array}$ \\
\hline Central Europe Low & $\mathrm{TM}$ & Central European Low \\
\hline & $\mathrm{U}$ & Undefined \\
\hline
\end{tabular}

\section{Results}

\subsection{Mean annual day-to-day changes of Tmax and Tmin}

In the analysed period 1966-2015, the mean annual day-to-day changes in Tmax and Tmin in Poland were $2.3^{\circ} \mathrm{C}$ and $2.5^{\circ} \mathrm{C}$, respectively, and showed spatial variability (Table 2, Figure 2). Mean day-to-day changes in Tmax increased from the north to the south of the country and ranged from 
$2.1{ }^{\circ} \mathrm{C}$ in Łeba, Świnoujście, and Chojnice to $2.5^{\circ} \mathrm{C}$ in Kraków. Mean changes in Tmin were lowest in the western part of Poland and increased eastwards generally except for the central-eastern area which is characterised by slightly lower values. They varied from $2.0^{\circ} \mathrm{C}$ in Świnoujście and Zielona Góra to $2.7^{\circ} \mathrm{C}$ in Wrocław, Toruń, Kielce, Rzeszów, and Białystok.
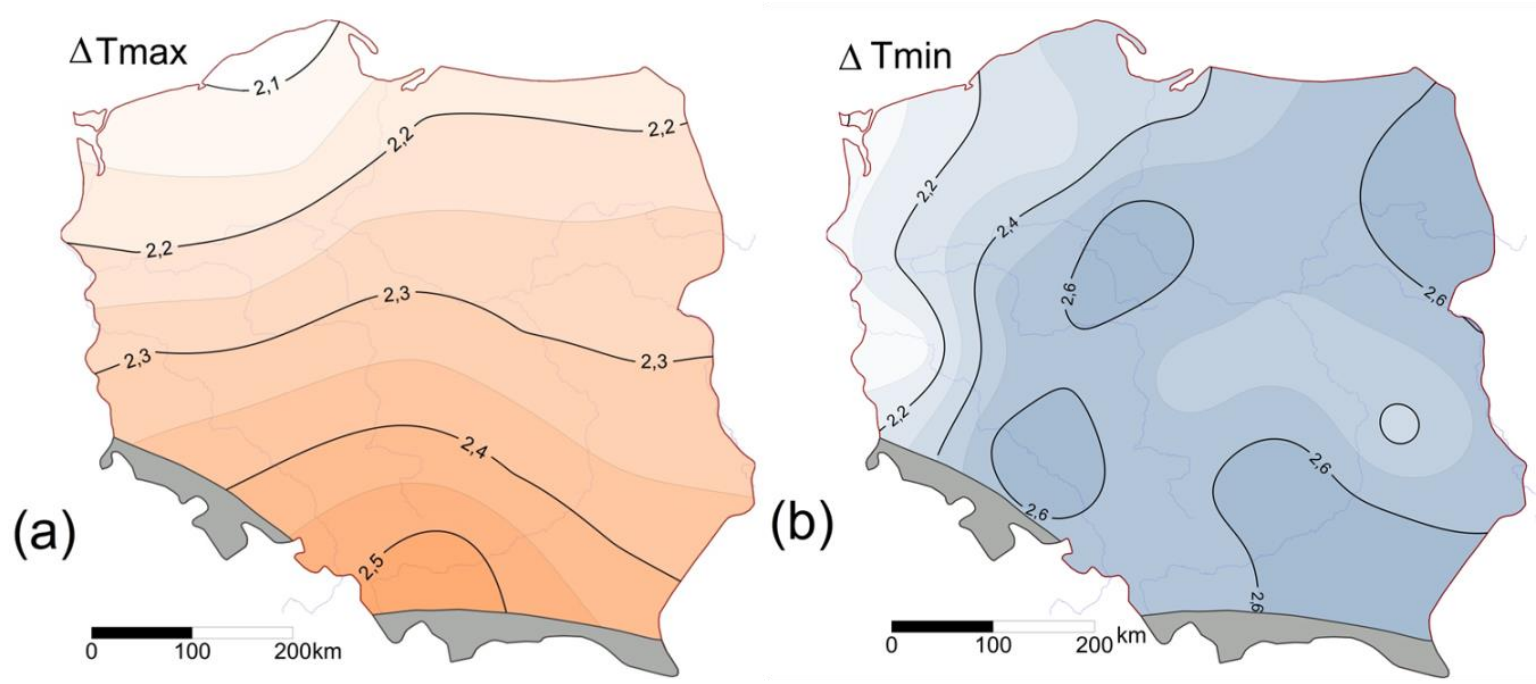

Figure 2. Average annual day-to-day changes of Tmax (a) and Tmin (b) in Poland in the years 1966-2015.

Mean day-to-day change in Tmax in Poland was the most considerable in 1983, reaching $2.5^{\circ} \mathrm{C}$, and the lowest in 1974, reaching $2.0^{\circ} \mathrm{C}$. In particular stations, their values and year of occurrence were variable. They varied from $2.9^{\circ} \mathrm{C}$ in Kraków in 1983 to $1.8^{\circ} \mathrm{C}$ in Świnoujście in 1974. In the analysed multiannual period, the highest number of stations with the highest mean day-to-day change in Tmax, i.e., 6 out of 18 of the analysed stations, was recorded in 1983 and 2012, although the stations were different in each year. 2006 was the year with the highest number of stations ( 5 out of 18 stations) with the lowest mean day-to-day change in Tmax.

Mean day-to-day change in Tmin in Poland was the highest in 2012, reaching $3.2^{\circ} \mathrm{C}$, and the lowest, reaching $2.2^{\circ} \mathrm{C}$, in 1972 . The highest value of $3.2^{\circ} \mathrm{C}$ were recorded in Białystok (2012), Kielce (1987), Rzeszów (1987), Terespol (1987), and Toruń (2003). The lowest one, i.e., $1.6{ }^{\circ} \mathrm{C}$, was recorded in Świnoujście (1984). In 1987, the highest number of stations was characterised by the highest mean day-to-day change in Tmax - 5 out of 18 stations. The lowest mean of the discussed changes in Tmin occurred twice: in 1972 and 1974 (6 stations out of 18).

The dynamics of mean annual changes from year to year in temperature, Tmax and Tmin, in the majority of the territory of Poland is similar. Mean changes for the entire country showed a statistically significant increase in changes in extreme temperature (Figure 3). $72 \%$ of the analysed stations showed an increase in mean changes in both Tmax and Tmin (Figure 4). Only in Świnoujście and in Warsaw, this trend is statistically significant in the case of Tmax. In the case of Tmin, a statistically significant increasing trend is typical of Białystok, Chojnice, Łódź, Terespol, Torun, and Wrocław. In Rzeszów, a decrease in these changes in the range of Tmax and a lack of changes in the case of changes in Tmin are observed. The stations in Toruń, Poznań, and Wrocław are characterised by a negative tendency of changes in Tmax and positive in Tmin. Stations in Świnoujście and Zielona Góra deserve particular attention, where year-to-year changes in Tmax and Tmin show an increasing tendency, although the mean annual changes in Tmax are higher than Tmin, unlike in the remaining stations. 


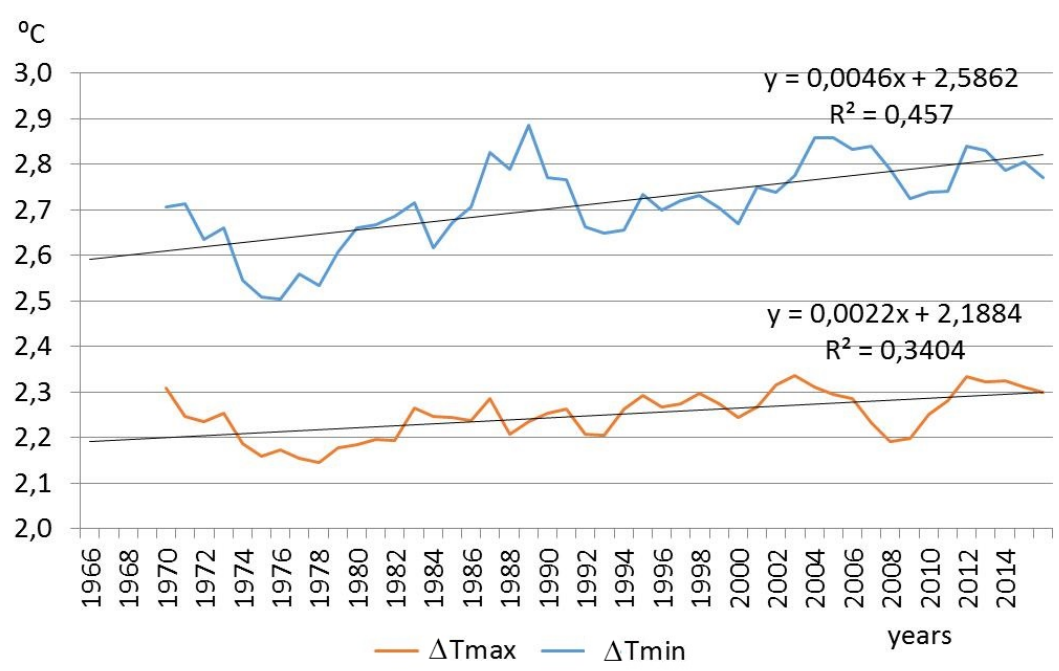

Figure 3. Fluctuation of 5-year moving mean of day-by-day Tmax and Tmin changes in Poland in the years 1966-2015.
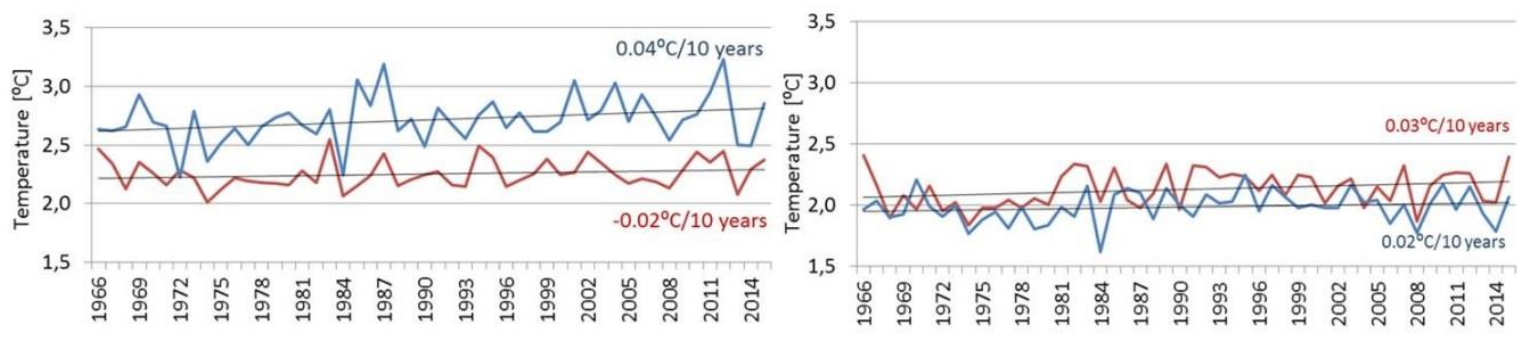

Białystok $\quad-\Delta \operatorname{Tmax}-\Delta \operatorname{Tmin}$

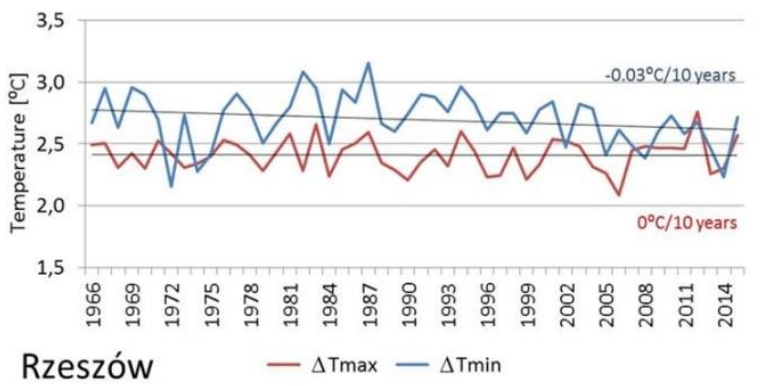

Świnoujście $\quad-\Delta \operatorname{Tmax}-\Delta T \operatorname{Tmin}$

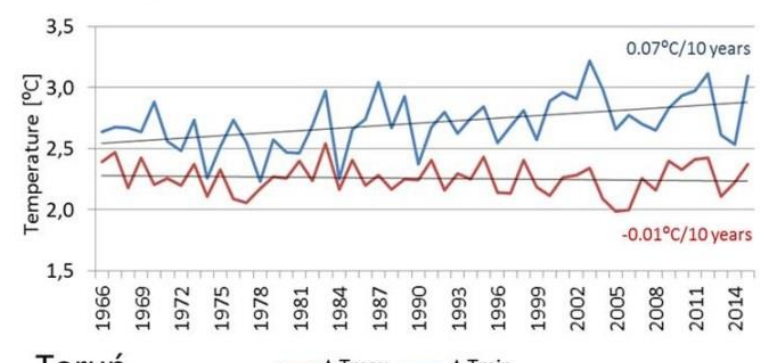

Figure 4. Annual mean day-by-day $\Delta \mathrm{Tmax}$ and $\Delta \mathrm{Tmin}$ course in selected stations in Poland in the years 1966-2015 with the trend lines.

\subsection{Large day-to-day changes of Tmax and Tmin}

The total annual number of large day-to-day changes in maximum temperature $\left(\Delta \operatorname{Tmax} \geq 6{ }^{\circ} \mathrm{C}\right)$ in the analysed stations in Poland in the research period is 340 cases with $\Delta \mathrm{Tmax} \geq 6{ }^{\circ} \mathrm{C}$. The number varied in particular stations from 16/year in Chojnice and Elbląg to 25 cases/year in Kraków. In the discussed period, just an average of 6 cases of $\Delta$ Tmax $\geq 12^{\circ} \mathrm{C}$ occurred annually, from 0.2 cases/year in Gorzów Wielkopolski to 0.8 cases/year in Świnoujście.

The total number of large interdiurnal changes in minimum temperature $\left(\Delta \operatorname{Tmin} \geq 6{ }^{\circ} \mathrm{C}\right)$ in the selected stations in Poland in the analysed period averaged 445 cases annually, varying from 35 in Kielce to 9 in Świnoujście. Very large changes in minimum temperature $\left(\Delta \operatorname{Tmin} \geq 12{ }^{\circ} \mathrm{C}\right)$ in Poland occurred on average 13 times in a year in the period 1966-2015 - from 0.1 cases in Gorzów Wielkopolski and Zielona Góra to 1.6 in Suwałki. 
In the years 1966-2015, the average annual number of cases of increases in large changes in $\operatorname{Tmax}\left(\Delta \operatorname{Tmax} \uparrow \geq 6{ }^{\circ} \mathrm{C}\right)$ in Poland reached 165 and showed spatial variability. A high increase in Tmax usually occurred at the coast and near Kraków (more than 12) (Figure 5a). The least cases of such changes occurred in the belt of lakelands (below 8). Decreases in large changes in Tmax $\left(\Delta \operatorname{Tmax} \downarrow \geq 6{ }^{\circ} \mathrm{C}\right)$ were recorded in Poland on average 175 times in a year, and their number increased from the north-east to the south-west of the country. They most commonly occurred in the foothills of the Carpathians (more than 12), and most seldom in north-western Poland (below 8) (Figure 5b). Very large increases in maximum temperature $\left(\Delta \operatorname{Tmax} \uparrow \geq 12{ }^{\circ} \mathrm{C}\right)$ are very rare: up to 0,5 cases annually in Świnoujście and occasional occurrences in central Poland (Figure 5c). Very large decreases in $\operatorname{Tmax}\left(\Delta \operatorname{Tmax} \downarrow \geq 12^{\circ} \mathrm{C}\right)$ were also infrequent: up to 0,3 cases/year in Kraków and Lublin (Figure 5d).
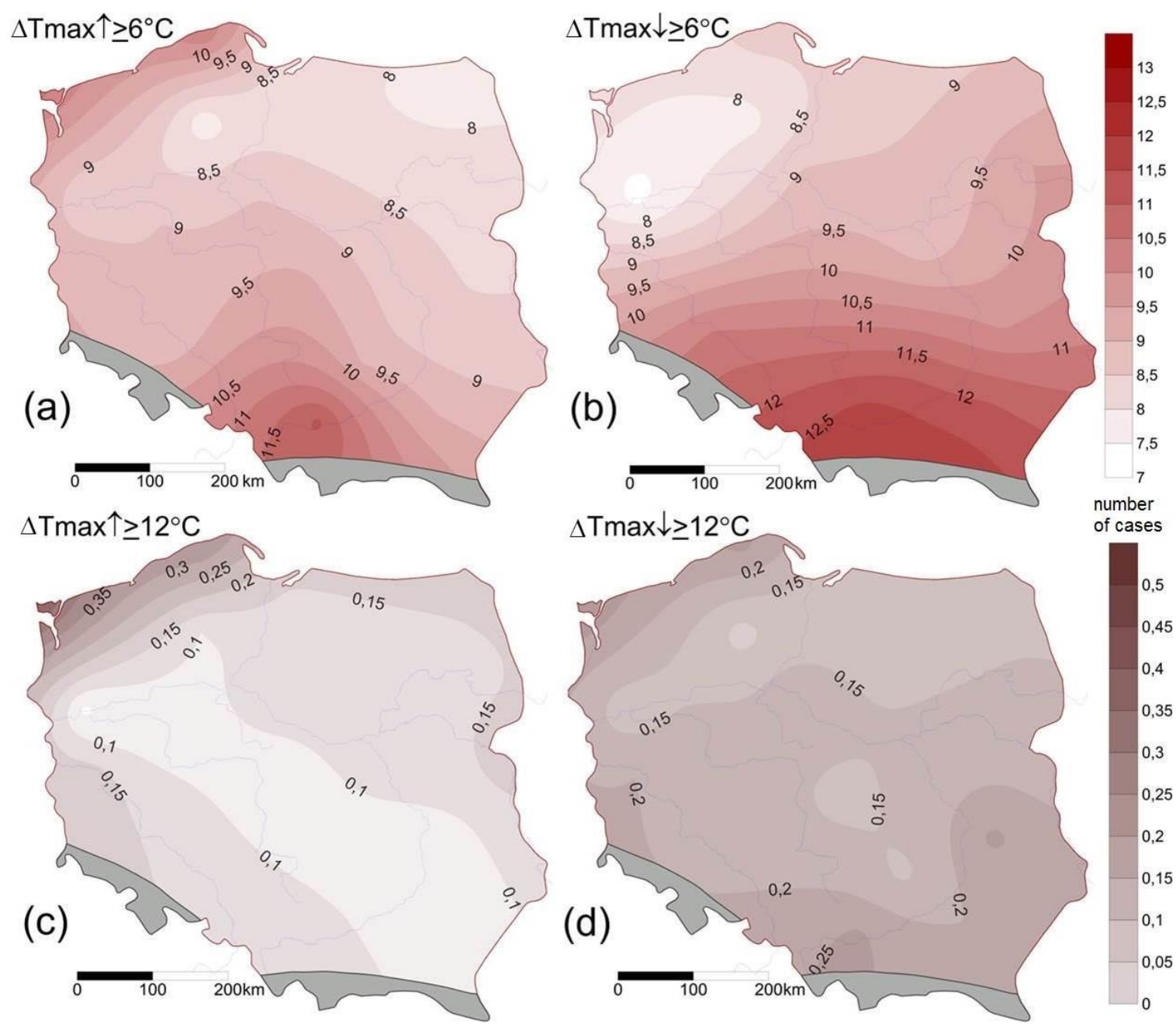

Figure 5. Spatial distribution of annual averages of large interdiurnal increases (a) and decreases (b) and very large increases (c) and very large decreases (d) in Tmax in Poland in the years 1966-2015.

Large increases in $\operatorname{Tmin}\left(\Delta \operatorname{Tmin} \uparrow \geq 6^{\circ} \mathrm{C}\right)$ in Poland occurred 255 times a year. Their number generally increased from the west to the east of the country, varying from 6 cases in Zielona Góra and Świnoujście to 19 cases annually in Rzeszów (Figure 6a). Decreases in large changes in Tmin $\left(\Delta \operatorname{Tmin} \downarrow \geq 6^{\circ} \mathrm{C}\right.$ ) in Poland were recorded on average 190 times in a year, and the spatial distribution of their number was variable (Figure $6 b$ ). They occurred most seldom in the north-western part of the country with the lowest number of cases recorded in Świnoujście (3 times in a year). The highest 
number of large decreases in Tmin was recorded in stations in Kielce, Rzeszów, and Białystok (more than 15). Very large increases in minimum temperature $\left(\Delta \operatorname{Tmin} \uparrow \geq 12^{\circ} \mathrm{C}\right)$ were the most common of all the very large variations within the range of 0,1 cases/year in northeastern Poland to 1,1 cases annually in Białystok (Figure 6c). Very large decreases in $\operatorname{Tmin}\left(\Delta \operatorname{Tmin} \downarrow \geq 12{ }^{\circ} \mathrm{C}\right.$ ) did not exceed 0.6 cases a year in Suwałki (Figure 6d).
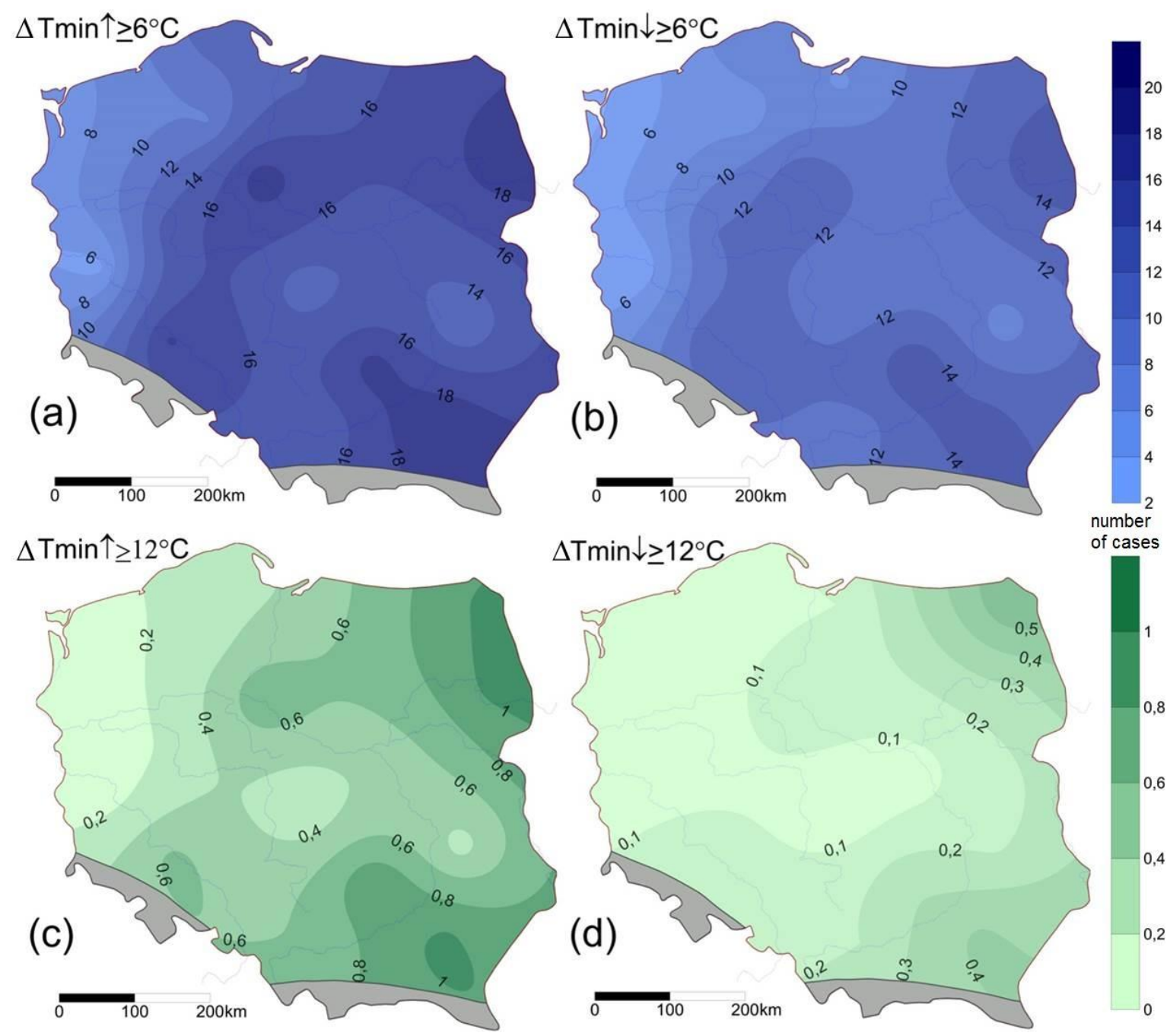

Figure 6. Spatial distribution of annual averages of large interdiurnal increases (a) and decreases (b) and very large increases (c) and very large decreases (d) in Tmin in Poland in the years 1966-2015.

In the analysed period, the mean monthly number of days with large changes in $\operatorname{Tmax}\left(\geq 6{ }^{\circ} \mathrm{C}\right)$ in Poland reached 19 cases in a year, including 9 increases and 10 decreases. The number of days with these changes in Tmin reached 25, including 14 increases and 11 decreases. Large changes in Tmax dominated in April and May, Tmin - from December to March (Figure 7). The lowest number of large changes in Tmax occurred in February and the period from August to November. Large changes in Tmin occurred most seldom from June to August and in November. 


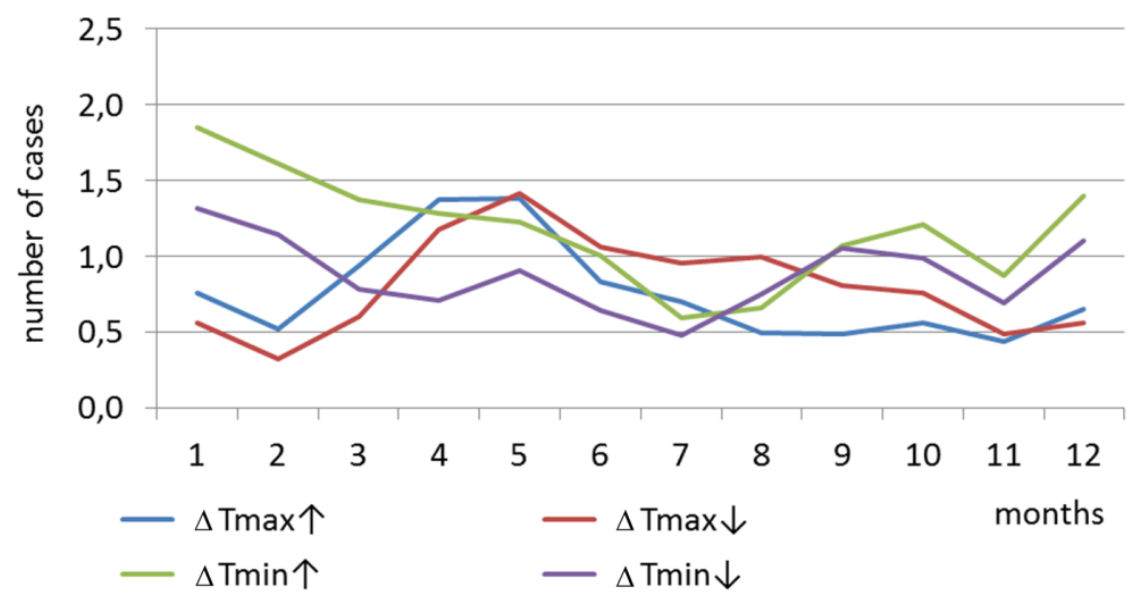

Figure 7. Mean monthly number of cases of large day-to-day increase and decrease in Tmax $(\Delta \operatorname{Tmax} \uparrow ; \Delta \operatorname{Tmax} \downarrow)$ and $\operatorname{Tmin}(\Delta \operatorname{Tm} \min \uparrow ; \Delta \operatorname{Tm} \min \downarrow)$ in Poland in the years 1966-2015.

Among the annual courses of large changes in maximum temperature in all the analysed stations, coastal stations stand out (Świnoujście and Łeba), showing the highest variability of the number of cases in a year. The highest monthly number of increases and decreases in Tmax is observed in May there, and their lowest number in November (Figure 8). Very large changes in Tmax $\left(\geq 12{ }^{\circ} \mathrm{C}\right)$ also occur most frequently in these stations, with the highest number of cases recorded in May.
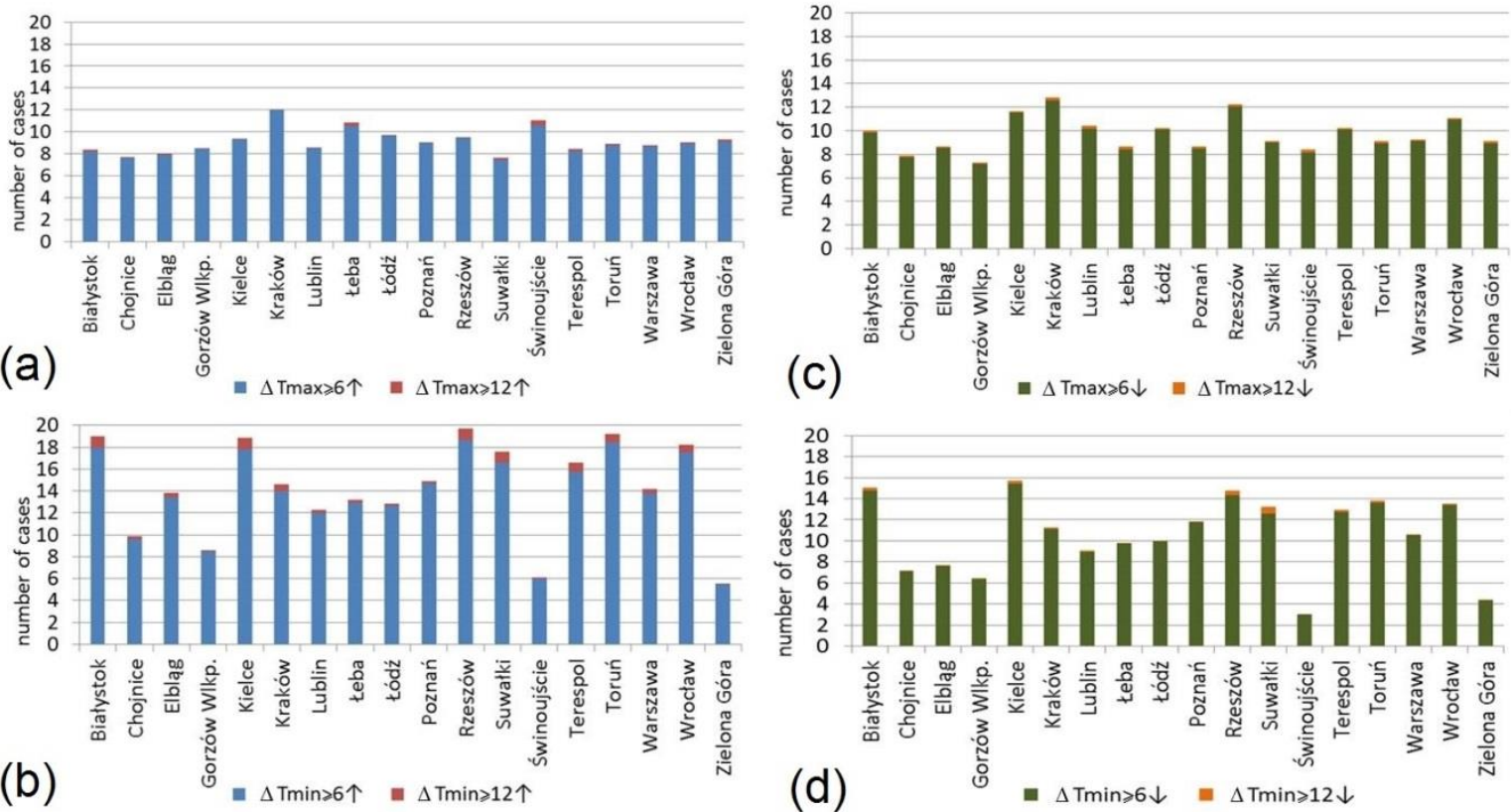

Figure 8. Mean annual number of cases of large and very large day-to-day increase $(a, b)$ and decrease (c, d) in $\operatorname{Tmax}(\Delta \operatorname{Tmax} \uparrow ; \Delta \operatorname{Tmax} \downarrow)$ and $\operatorname{Tmin}(\Delta \operatorname{Tmin} \uparrow ; \Delta \operatorname{Tmin} \downarrow)$ in Poland in years 1966-2015.

Considering the annual course of the number of large changes in Tmin, the stations in Świnoujście, Zielona Góra, Białystok, and Suwałki stand out. Świnoujście is a station characterised by the lowest monthly number of decreases in Tmin, particularly in July and in September (7 cases at each). Zielona Góra is characterised by the lowest number of decreases in Tmin, particularly in July (9). In Suwałki, the highest monthly number of increases in Tmin was observed in February, and the decreases in January (123 and 94 cases, respectively), and in Białystok a high increase in Tmin 
usually occurred in January, and a decrease in February (115 and 105 cases, respectively). The variability of the number of increases in Tmin of more than $12{ }^{\circ} \mathrm{C}$ also deserves attention - their highest number was recorded in February in Suwałki (19) and Białystok (17) and in January in Kielce (18) and Terespol (16). Very high decreases in Tmin usually occurred in January in Rzeszów (13) and Suwałki in January and December (13 and 11, respectively).

During the period considered in all the analysed stations in Poland, the highest daily decrease in Tmax exceeded $14{ }^{\circ} \mathrm{C}$, and the increase exceeded $13{ }^{\circ} \mathrm{C}$ (Figure 9). The highest decreases in particular stations varied from $-14.1{ }^{\circ} \mathrm{C}$ in Torun (19.10.1967) to $-23.6{ }^{\circ} \mathrm{C}$ in Raciborz (27.05.2014). Maximum increases in Tmax ranged from $13.1{ }^{\circ} \mathrm{C}$ in Rzeszów (11.02.1966) to $19.8^{\circ} \mathrm{C}$ in Świnoujście (14.05.1985). The highest daily decrease in Tmin exceeded $10^{\circ} \mathrm{C}$, and the increase $12{ }^{\circ} \mathrm{C}$. Maximum decreases in Tmin in particular stations are values from $10.3^{\circ} \mathrm{C}$ in Świnoujście (13.12.2001) to $22.1^{\circ} \mathrm{C}$ in Kielce (7.01.1987). Maximum increases in Tmin varied from $12.8^{\circ} \mathrm{C}$ in Zielona Góra (6.02.2001) to $21.7^{\circ} \mathrm{C}$ in Kielce (11.01.1970).
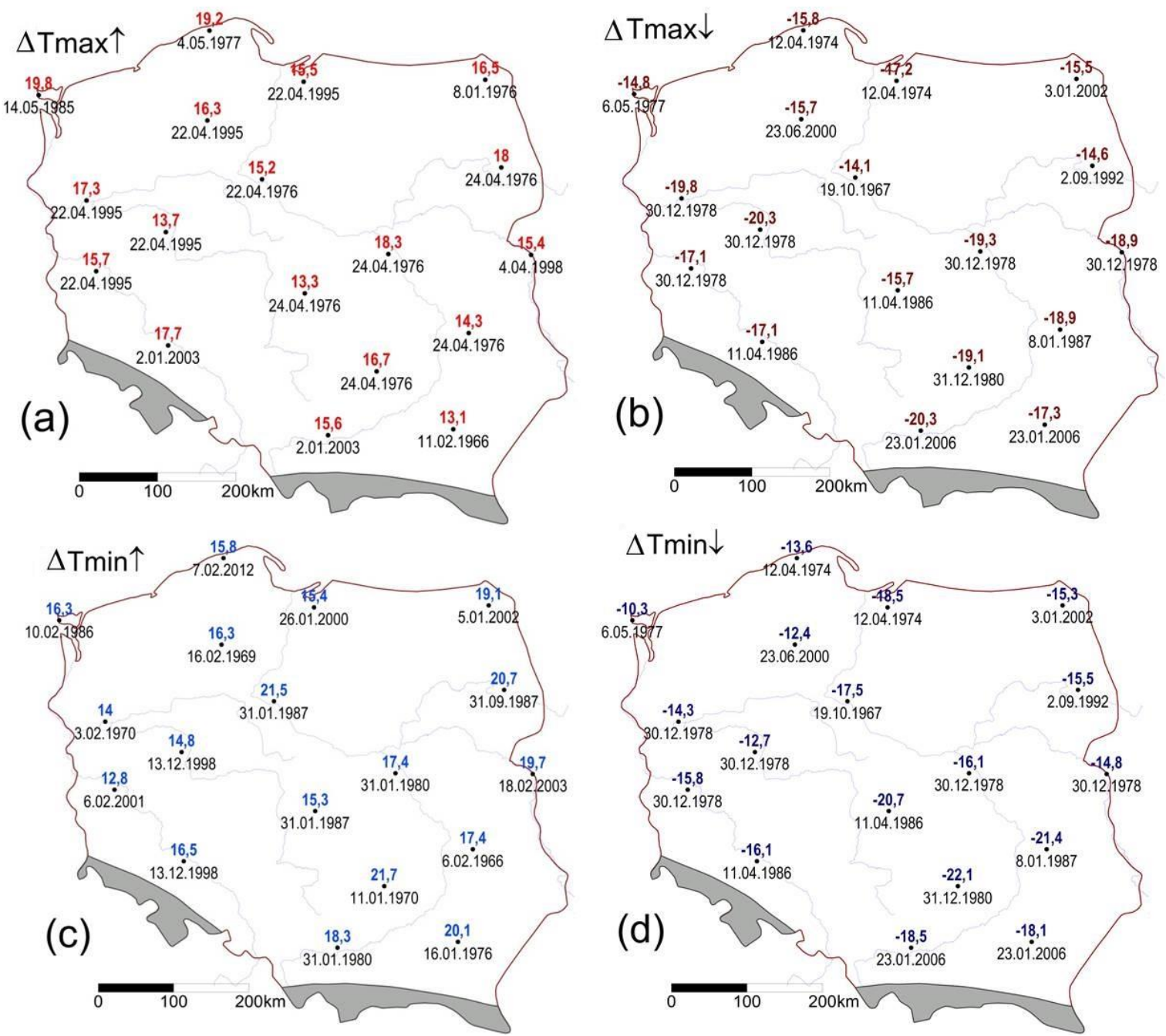

Figure 9. The highest interdiurnal increases and decreases in $\operatorname{Tmax}(a, b)$ and $\operatorname{Tmin}(c, d)$ in Poland in 1966-2015 with the date of its occurrence.

The share of all decreases and increases in temperature in the case of Tmax is more even in comparison to Tmin (Table 3). On average in Poland, in $49.4 \%$ of cases, an increase in Tmax occurred, and in $48.9 \%$ of cases a Tmax decrease.

Interdiurnal Tmax increases occur slightly more frequently in the north-west of Poland. The stations in the north-western part of the country are characterised by the advantage of an increase in Tmax over a decrease. The remaining area is dominated by interdiurnal declines in Tmax. 
Interdiurnal Tmax increases occur slightly more frequently in the north-west of Poland. The stations in the north-western part of the country are characterised by the advantage of an increase in Tmax over a decrease. The remaining area is dominated by interdiurnal declines in Tmax. In Świnoujście, the variation in the share is the greatest $(\Delta \operatorname{Tmax} \uparrow=46.8 \%, \Delta \operatorname{Tmax} \downarrow=50.8 \%)$, and lack of it in Torun $(\Delta \operatorname{Tmax} \uparrow$ and $\Delta \mathrm{Tmax} \downarrow=49.1 \%)$.

Throughout the country, a day-to-day decrease in minimum temperature occurs more frequently, averaging $50.7 \%$ of cases. The share of increases in Tmin averages $47.6 \%$ in Poland. The stations in the north of the country and located in the area from Elblag to Poznan are characterised by the greatest advantage of Tmin decreases over increases. In Elblag, the range of the share is the biggest $(\Delta \operatorname{Tmin} \uparrow=46,7 \%, \Delta \operatorname{Tmin} \downarrow=51,7 \%)$, and in Lublin the smallest $(\Delta \operatorname{Tmin} \uparrow=48,5 \%, \Delta \operatorname{Tmin} \downarrow=$ $50,0 \%$ ). Days with no changes either in Tmax or Tmin constitute $1.7 \%$ of cases.

Table 3. The share of all $\left(>\mathbf{0}^{\circ} \mathbf{C}\right)$ and large increases, decreases $\left(\geq 6^{\circ} \mathrm{C}\right)$, and no day-to-day changes in Tmax and Tmin in selected stations in Poland in the years 1966-2015.

\begin{tabular}{|c|c|c|c|c|c|c|c|c|c|c|}
\hline \multirow[b]{3}{*}{ Station } & \multicolumn{5}{|c|}{ Maximum temperature } & \multicolumn{5}{|c|}{ Minimum temperature } \\
\hline & \multicolumn{3}{|c|}{$\Delta \mathrm{Tmax} \geq 0{ }^{\circ} \mathrm{C}$} & \multicolumn{2}{|c|}{$\Delta \operatorname{Tmax} \geq 6{ }^{\circ} \mathrm{C}$} & \multicolumn{3}{|c|}{$\Delta \mathrm{Tmin} \geq 0{ }^{\circ} \mathrm{C}$} & \multicolumn{2}{|c|}{$\Delta \mathrm{Tmin} \geq 6^{\circ} \mathrm{C}$} \\
\hline & 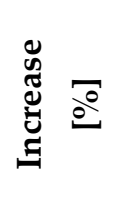 & 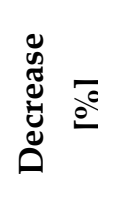 & 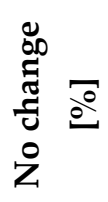 & 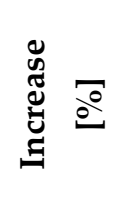 & 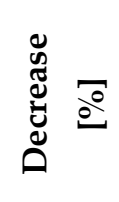 & 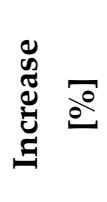 & 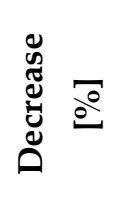 & 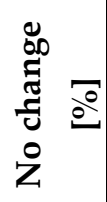 & 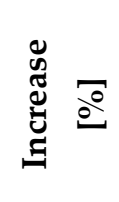 & 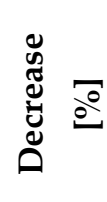 \\
\hline Białystok & 50.1 & 47.9 & 2.0 & 45.5 & 54.5 & 47.8 & 50.7 & 1.5 & 55.8 & 44.2 \\
\hline Chojnice & 48.8 & 49.0 & 2.2 & 49.6 & 50.4 & 47.7 & 50.3 & 1.9 & 57.8 & 42.2 \\
\hline Elbląg & 49.1 & 49.3 & 1.7 & 48.1 & 51.9 & 46.7 & 51.7 & 1.6 & 64.2 & 35.8 \\
\hline Gorzów Wlkp. & 48.2 & 50.2 & 1.6 & 53.7 & 46.3 & 47.9 & 50.5 & 1.6 & 57.3 & 42.7 \\
\hline Kielce & 50.7 & 47.8 & 1.5 & 44.5 & 55.5 & 47.8 & 50.6 & 1.5 & 54.5 & 45.5 \\
\hline Kraków & 49.6 & 49.1 & 1.4 & 48.5 & 51.5 & 47.9 & 50.5 & 1.6 & 56.4 & 43.6 \\
\hline Lublin & 50.7 & 47.9 & 1.4 & 45.2 & 54.8 & 48.4 & 50.0 & 1.6 & 57.5 & 42.5 \\
\hline Łeba & 47.7 & 50.1 & 2.2 & 55.5 & 44.5 & 46.9 & 51.2 & 1.9 & 57.3 & 42.7 \\
\hline Łódź & 49.9 & 48.5 & 1.6 & 48.7 & 51.3 & 47.8 & 50.3 & 1.8 & 56.2 & 43.8 \\
\hline Poznań & 49.0 & 49.4 & 1.7 & 51.0 & 49.0 & 47.2 & 51.2 & 1.5 & 55.7 & 44.3 \\
\hline Rzeszów & 50.8 & 47.7 & 1.5 & 43.7 & 56.3 & 47.7 & 50.6 & 1.7 & 57.2 & 42.8 \\
\hline Suwałki & 49.5 & 48.4 & 2.1 & 45.5 & 54.5 & 47.2 & 50.9 & 1.9 & 57.1 & 42.9 \\
\hline Świnoujście & 46.8 & 50.8 & 2.3 & 56.8 & 43.2 & 46.8 & 51.1 & 2.1 & 66.7 & 33.3 \\
\hline Terespol & 50.1 & 48.2 & 1.6 & 45.1 & 54.9 & 47.9 & 50.4 & 1.7 & 56.2 & 43.8 \\
\hline Toruń & 49.1 & 49.1 & 1.8 & 49.4 & 50.6 & 47.2 & 51.4 & 1.4 & 58.2 & 41.8 \\
\hline Warszawa & 49.7 & 48.6 & 1.7 & 48.7 & 51.3 & 47.8 & 50.6 & 1.6 & 57.2 & 42.8 \\
\hline Wrocław & 49.7 & 48.7 & 1.5 & 44.8 & 55.2 & 47.9 & 50.7 & 1.4 & 57.3 & 42.7 \\
\hline Zielona Góra & 48.2 & 50.3 & 1.6 & 50.5 & 49.5 & 48.0 & 50.2 & 1.8 & 55.7 & 44.3 \\
\hline Mean & 49.4 & 48.9 & 1.7 & 48.6 & 51.4 & 47.6 & 50.7 & 1.7 & 57.7 & 42.3 \\
\hline
\end{tabular}

Considering the share of large changes in Tmax and Tmin, a predominant share of large interdiurnal changes in Tmin over Tmax (56.7\% and 43.3\% respectively) in Poland is found. When considering the share of large increases and decreases in the case of Tmax, spatial differentiation is noticeable (Table 2). Tmax most often increases day-by-day on the coast and in the western part of the country. The maximum occurs in Świnoujście of $56.8 \%$, which is also characterised by the 
greatest variation in the share of increases and decreases in $\operatorname{Tmax}(\Delta \operatorname{Tmax} \uparrow=56.8 \%, \Delta \operatorname{Tmax} \downarrow=43.2$ $\%)$. The smallest share of Tmax increases was recorded in southeastern and eastern Poland, with the minimum in Rzeszów (43.7\%). In this region also, Tmax declines are the highest with the maximum in Rzeszów (56.3\%). The lowest share of decreases is in Świnoujście (43.2\%). On the other hand, in the case of Tmin, the day-to-day increases are more frequent than decreases. The highest share of increases is recorded at the stations in Świnoujście and Elbląg. Świnoujście has the highest variation in share $(\Delta \operatorname{Tm} \min \uparrow=6.7 \%, \Delta \operatorname{Tm} \min \downarrow=33.3 \%)$, and the lowest - in Kielce $(\Delta \operatorname{Tmin} \uparrow=54.5 \%$ and $\Delta \operatorname{Tmin} \downarrow$ $=45.5 \%)$.

\subsection{Influence of atmospheric circulation}

In the years 1966-2015, circulation types WZ (15.5\%) and BM (10.8\%) occurred the most frequently (Figure 10). The following types occurred the most seldom, with a frequency below $2 \%$ : NA $(0.6 \%)$ and SZ $(0.8 \%)$, as well as HFZ (1.7\%), HNA (1.8\%), HNFA (1.3\%), HNFZ (1.9\%), HNZ $(1.6 \%)$, NEA $(1.1 \%)$, NEZ $(1.4 \%)$, SA $(1.6 \%)$, SEZ (1.4\%). In the aforementioned period, cyclonic circulation considerably dominated (57.0\%) over anticyclonic circulation $(41.9 \%)$.

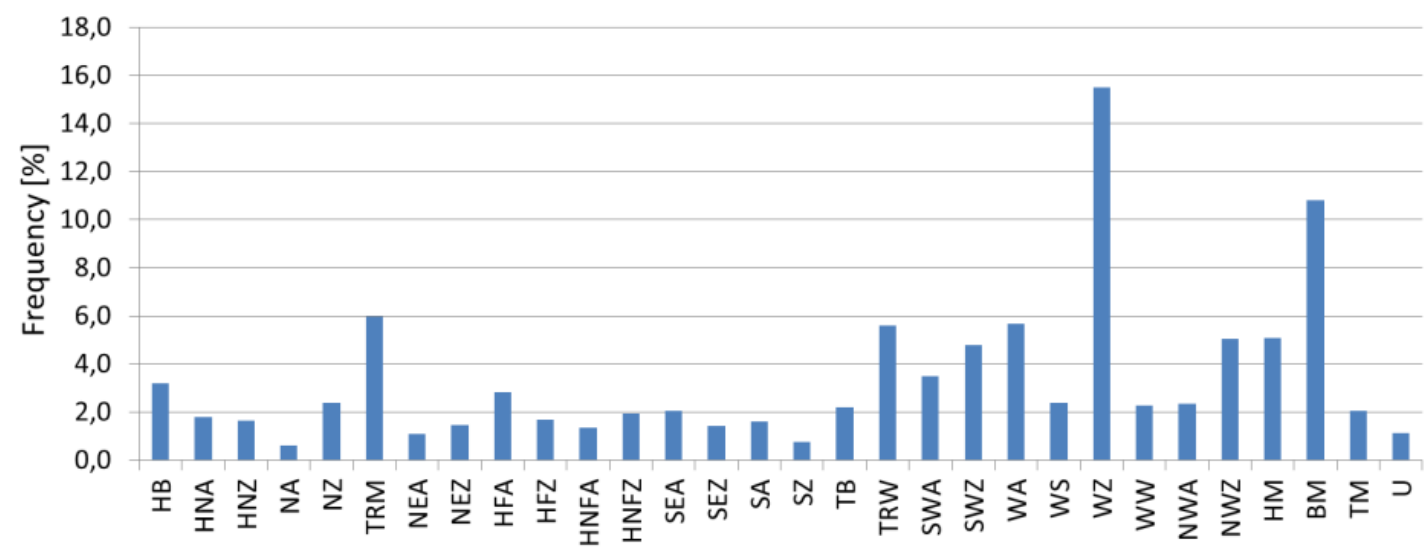

Figure 10. Frequency of Grosswetterlagen (GWL) circulation types in the years 1966-2015. Explanations of the GWL types: see Table 2.

Large day-to-day changes in Tmax primarily occurred during cyclonic circulation (62.8\%). The highest probability of occurrence of a large increase in maximum temperature was recorded during SWZ (8.0\%) (Figure 11a). High probabilities of $\Delta \operatorname{Tmax} \geq 6^{\circ} \mathrm{C}$ also occurred during types TRW $(7.1 \%)$, SZ $(7.1 \%)$, and TB (7.0\%). The lowest probability of a large increase in Tmax was related to SEA and TRM (1.6\% each). A large decrease in Tmax was the most probable during NEA and HNZ circulation (5.4\% each) (Figure 11b). Such changes also occurred relatively frequently with types TRM (4.5\%) and TRW (4.3\%). They were recorded most seldom during types TB (1.0\%) and HFA $(1.4 \%)$. 

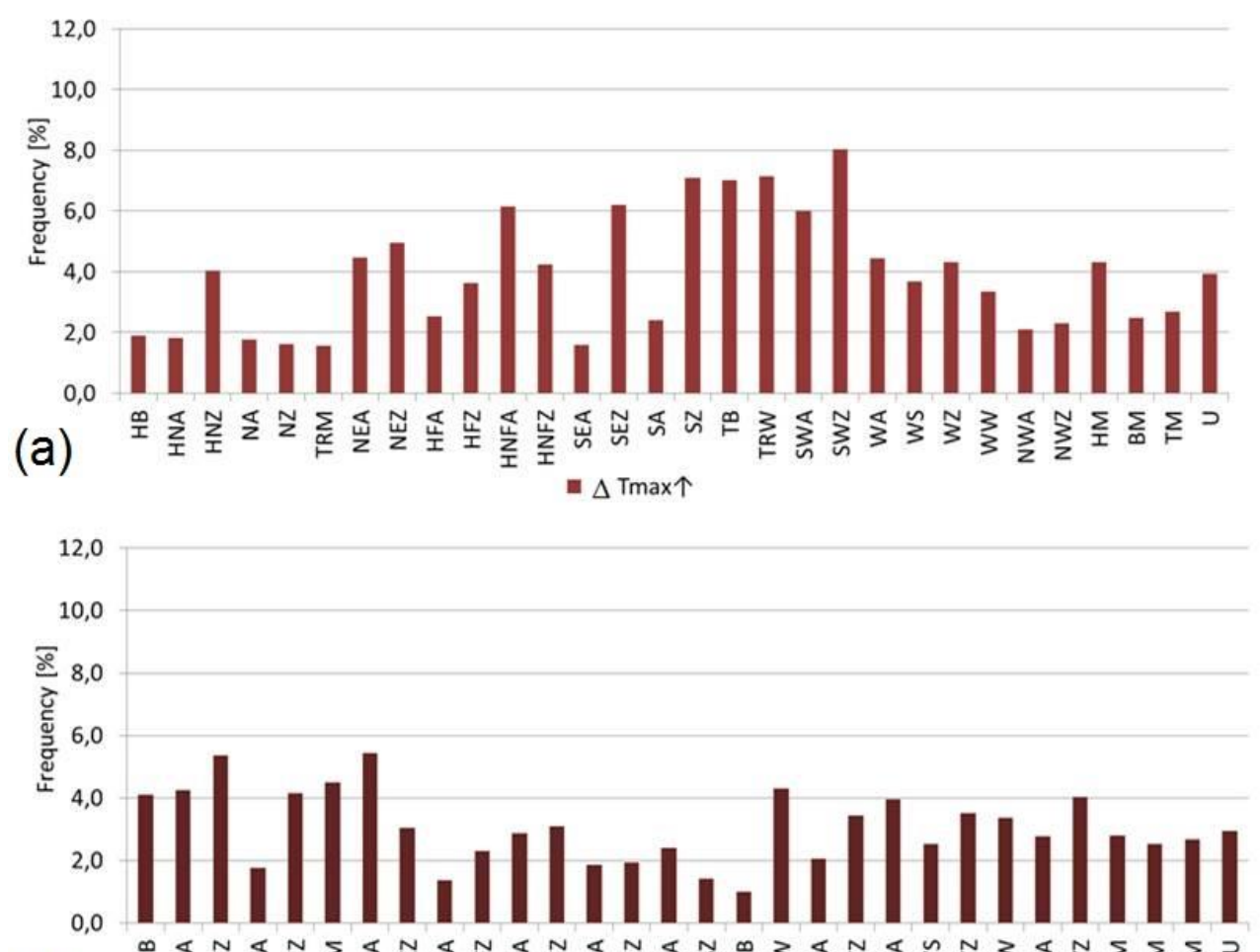

(b)

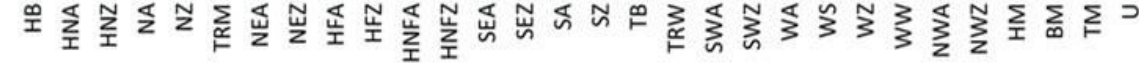

- $\Delta \operatorname{Tmax} \downarrow$

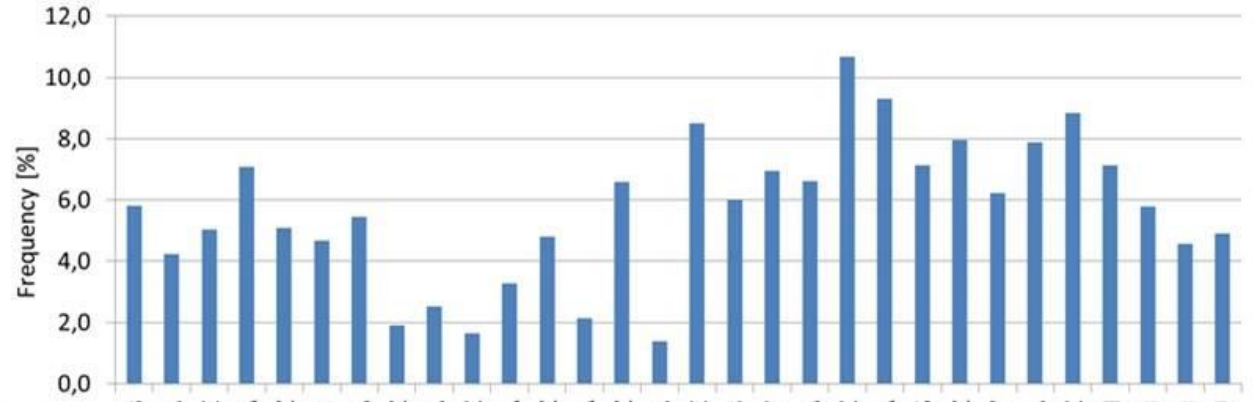

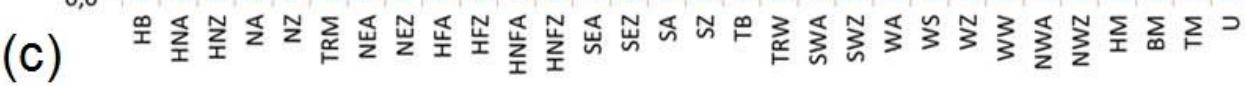

$\Delta \min \uparrow$

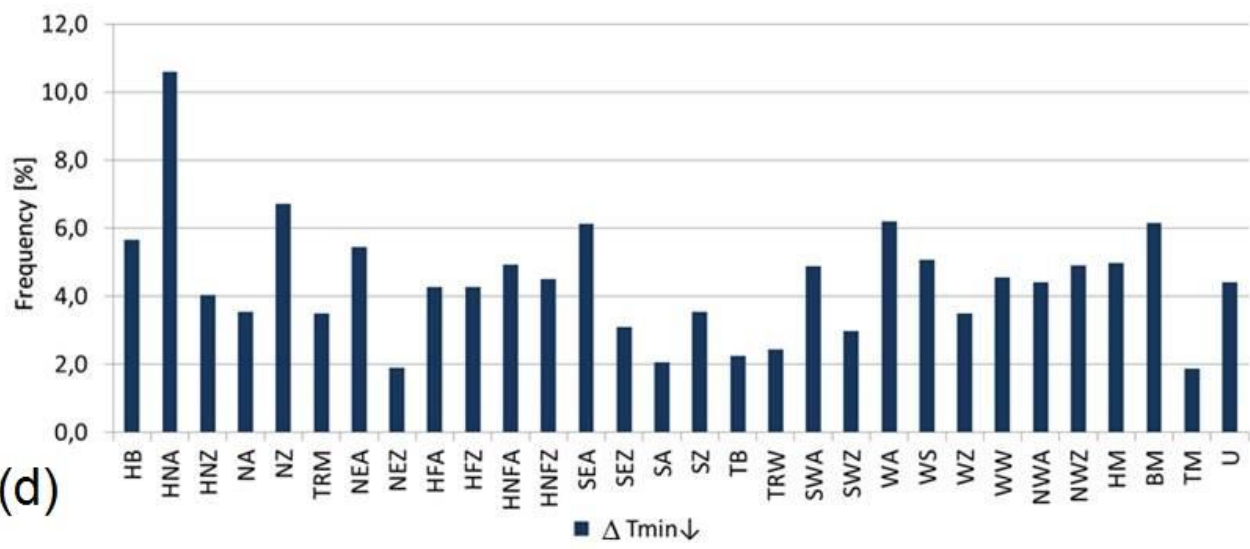

Figure 11. Probability of the occurrence of large interdiurnal of extreme temperature changes in the particular GWL circulation types in the years 1966-2015. (a) $\Delta \operatorname{Tmax} \uparrow$; (b) $\Delta \operatorname{Tmax} \downarrow$ (c), $\Delta \operatorname{Tmin} \uparrow$; (d) $\Delta \operatorname{Tmin} \downarrow$. Explanations of the GWL types: see Table 2.

Large day-to-day changes in Tmin usually occurred during cyclonic circulation types, reaching $83.5 \%$ on the whole. The highest probability of occurrence of a large increase in minimum 
temperature was recorded during SWZ (10.7\%) (Figure 11c). Moreover, circulation types WA (9.3\%), NWZ (8.8\%), and SZ (8.5\%) favoured high increases in Tmin. The lowest probability of a high increase in Tmin was usually related to circulation types SA (1.4\%) and HFZ (1.6\%). The highest probability of occurrence of a high decrease in Tmin was recorded in type HNA (10.6\%) (Figure 11d). A higher number of large day-to-day changes in Tmin was also probable during circulation NZ $(6.7 \%)$, WA $(6.2 \%)$, as well as SEA and BM $(6.1 \%$ each). The lowest probability of a high day-to-day decrease in Tmin occurred in types TM and NEZ (1.9\% each).

A very high increase in Tmax over the predominant territory of Poland, i.e., a day-to-day increase of more than $12{ }^{\circ} \mathrm{C}$, occurred in the study period sporadically. It occurred one time during the following circulation types: NZ, HNZ, SWZ, and SEZ. A rapid day-to-day decrease in maximum temperature, i.e., a decrease by more than $12{ }^{\circ} \mathrm{C}$, occurred seven times in the study period in the majority of the analysed stations during the circulation types: HNFZ, WS, WZ, HNFA, NZ, HM, WA.

Very large changes in Tmin were recorded more frequently over a prevalent area of Poland. Day-to-day changes in Tmin $\geq 12{ }^{\circ} \mathrm{C}$ occurred 36 times in the period 1966-2015, and the highest probability of their occurrence was determined during SZ, NZ, HB, and SWZ types. A rapid decrease in Tmin was recorded 6 times: twice during type WS and one occurrence each during types: WZ, NZ, NWZ, and BM. All these cases of rapid changes in Tmin occurred in winter.

\section{Discussion and Summary}

In the analysed period 1966-2015, the mean annual day-to-day changes in Tmax and Tmin in Poland reached $2.3{ }^{\circ} \mathrm{C}$ and $2.5^{\circ} \mathrm{C}$, respectively, confirming earlier results $[11,12,21,22,23,24]$. The changes showed spatial variability reflecting the range of the effect of marine and continental properties on the climate of Poland. In the coastal region, day-to-day temperature changes are the least considerable as a manifestation of the mitigating effect of the sea on the climate [21]. According to Kossowska-Cezak [1], a very rapid change in thermal conditions in the lowland area of Poland is caused by the advection of air masses and the inflow of air from over a thermally contrasting surface.

Considerably more day-to-day changes in minimum than maximum temperature increase occurred in the analysed period. This is in accordance with the results of Panfil [22]. Similarly, Fortuniak et al. [7] determined that at the scale of the entire year, temperature increases are characterised by a lower mean value, but higher frequency than temperature decreases. This pattern is particularly evident in the warm season of the year. Regarding day-to-day variations, Piotrowicz et al. [24] pointed out that significant decreases in Tmax were more numerous than in Tmin, whereas the opposite was true for significant increases - they were more numerous in the case of Tmin than for Tmax.

In the years 1966-2015, the number of considerable changes in both Tmax and Tmin increased in Poland, although the variability shows spatial differentiation, and the changes are statistically significant only in some of the stations. A similar trend of changes was also found in north-eastern Poland - the direction of trends in the analysed stations was variable as Panfil [22] stated. Trends of multiannual changes in Olsztyn showed statistically significant increases and decreases only for Tmax [12]. In the major area of the territory of Poland, based on this research, higher ranges of large changes in maximum than minimum temperatures were recorded. Less increases in Tmax exceeding 10 degrees than Tmin were recorded in north-eastern Poland, but in the case of decreases, the number is approximate [22]. As Ciaranek [23] indicated, the rapid changes of $\operatorname{Tmax}\left(\geq 10{ }^{\circ} \mathrm{C}\right)$ in winter occurred in Poland more frequently in the first half of the analysed period 1961-2010. Therefore, if this tendency of changes is maintained, a decrease in the frequency of occurrence of rapid changes in maximum air temperature can be expected in the following years in Poland in the cold season.

The obtained results showed that the number of large Tmax fluctuations in Poland is variable latitudinally: it is the highest in the coastal area and increases from the north to the south of the 
country. The number of large changes in Tmin in Poland is the lowest in the northwestern part and increases east and southward. The presented results are consistent with the results of the research of Panfil and Dragańska [11], who within the analysed area of north-eastern Poland, designated areas with large $\left(\geq 6^{\circ} \mathrm{C}\right)$ day-to-day changes in temperature that occurred most frequently in the east.

The annual course of the number of both increases and decreases in Tmax reached culmination in spring, in accordance with the results of Panfil [22]. Changes in Tmin - both increase and decrease, are more considerable in winter than in summer, similarly proved by Wibig [21]. Fortuniak et al. [7] confirm that such considerable changes in temperature are usually observed in the winter period as a result of the advection of both cool and warm air masses. The temperature swings which are most strongly felt by the human body - not prepared to rapidly adapt to them - are mainly those occurring in winter and spring as a result of the advection of thermally different air masses, Kossowska-Cezak [9] explained. Kossowski [34] pointed out that significant short-term variations in temperature most frequently occur in the cooler half of the year when the air masses over Poland are the most thermally diverse and weather fronts are most frequent. In the summer months, such shifts are smaller and happen less frequently, while changes in cloud cover, which influence night-time radiation cooling, become a contributing factor $[24,26]$.

The share of temperature decreases and increases in the case of Tmax is more aligned in comparison to Tmin in the study period. On average in Poland, in $49.4 \%$ of cases, an increase in Tmax occurred, and in $48.9 \%$ of cases its decrease. A day-to-day decrease in Tmin occurs more frequently, averaging $50.7 \%$ of cases. The share of increases in Tmin averages $47.6 \%$ in Poland. While according to Ciaranek [23], in the years 1961-2010 in Poland, the share of increases in large changes in Tmax was lower than in the case of decreases and showed spatial variability.

Temperature changes at moderate latitudes remain in close relation to the variability of atmospheric circulation, particularly in winter when insolation plays a secondary role in forming weather conditions [21]. The research carried out showed that in Poland, day-to-day changes in Tmin exceeding 6 degrees are considerably more frequent in winter. Large changes in Tmax, however, show a higher frequency in spring. The majority of large day-to-day changes in Tmax, and particularly Tmin in accordance with the above analysis are related to cyclonic circulation types. However, the anticyclonic circulation types favour especially large decreases in Tmin. While Kuziemska [35] pointed to the important role of advection in shaping considerable temperature anomalies in winter, both positive and negative, whereas the most high temperature decreases occur when the inflow of cold air is accompanied by strong effective radiation, i.e. in the case of anticyclonic circulation types. In summer, the dominant role in shaping thermal conditions is played by insolation, and secondary, although still important, by advection. Kossowska-Cezak [9] evidenced that day-to-day temperature changes also depend on the sequence of circulation types. Day-to-day changes in minimum and maximum temperatures are usually the highest between the second and fourth day of occurrence of a given circulation, and then they decrease or even change the sign to the opposite one [21].

The study showed the variability of the direction of atmospheric advection favouring changes in Tmax and Tmin. Large increases in Tmax were favoured by the southern and southwestern circulation types and decreases - by the north and northeastern. High increases in Tmin were primarily favoured by the northern and western types and decreases by the northeastern types. The obtained results coincide with earlier studies. This is confirmed by research by Wibig [21], according to which western types are characterised by an increase in temperature, but maintain shorter for 4-5 days, and day-to-day changes are lower than in the case of eastern types. Eastern types are characterised by a day-to-day decrease in temperature maintained for 5-6 days. Panfil [12], analysing the dependencies of large changes in extreme temperatures on the atmospheric circulation in Olsztyn, proved a particular impact of the northern and westerly component. In winter, high decreases in temperature correspond to circulation types of the easterly component, particularly from the northern sector [1]. Moreover, Wibig and Głowicki [12] stated that day-to-day temperature changes are well correlated with cloudiness, and extreme temperature changes are related to the North Atlantic Oscillation, particularly in winter and spring. However, besides the weather situation and the advection of various air masses, the scale of short-term temperature changes is influenced by 
local factors, such as relief and land cover [36]. This suggests that the daily minimum temperature is less associated with the regional circulation patterns than the daily maximum temperature and more influenced by local factors instead. [36]. Piotrowicz et al. [24] suppose that the short-term variation in Tmax and Tmin decrease, which has been gradual over the entire analysed long-term period, without clear and sudden changes to the overall trend, was largely influenced by anthropogenic factors. The decrease in the daily temperature range is partially related to increases in cloud cover. Furthermore, a large number of atmospheric and surface boundary conditions are shown to differentially affect the maximum and minimum temperatures. For rural sites, day-to-day temperature variation was typically greater for Tmin than Tmax. The opposite was found for urban locations, with statistically significant stronger signals for larger cities [27].

Linkages of the observed changes in the diurnal temperature range to large-scale climate forcings, such as anthropogenic increases in sulfate aerosols, greenhouse gases, or biomass burning remain tentative $[3,27]$. Future research on temporal and spatial variability and the influence of local conditions on the occurrence of large changes in extreme temperatures would be not only valuable but also necessary.

\section{Conclusions}

The research on large day-to-day changes in extreme temperature in Poland in the period 1966-2015 and the influence of atmospheric circulation leads to the following conclusions:

- the number of large changes in both Tmax and Tmin slightly increased, although the fluctuations show spatial variability,

- higher fluctuations of maximum than minimum temperature were recorded over the majority of the territory of the country,

- the number of large changes in Tmax increases from north to south, and the number of large changes in Tmin from north to east and south of Poland,

- annual course of increases and decreases in both Tmax and Tmin is analogical, and the annual course of changes in Tmax and Tmin differs: large changes in Tmax occur more frequently in spring and Tmin in winter,

- the share of temperature increases in the case of Tmax is higher than that of decreases, and it is the opposite for Tmin,

- large changes in Tmax and Tmin are mainly recorded during cyclonic circulation, however, the anticyclonic circulation types favour especially large decreases in Tmin.

- large increases in Tmax were favoured by southern and southwestern circulation types, and decreases - by north and northeastern,

- large increases in Tmin were primarily favoured by northern and western types and decreases by northeastern types.

Conflicts of Interest: The author declares no conflict of interest.

\section{References}

1. Kossowska-Cezak, U. Duże zmiany temperatury z dnia na dzień w Polsce. Przegl. Geofiz. 1982, 27(3-4), 197-214.

2. Brazdil, R.; Budikova, M.; Auer, I.; Böhm, R.; Cegnar, T.; Fasko, P.; Gajič Capka, M.; Lapin, M.; Niedźwiedź, T.; Szalai, S.; Ustrnul, Z.; Weber, R.O.; Zaninovic, K. Trends of maximum and minimum daily temperature in Central and Southeastern Europe, Int. J. Climatol. 1996, 16, 765-782. doi:10.1002/(SICI)1097-0088(199607)16:7<765::AID-JOC46>3.0.CO;2-O

3. Karl, T.R.; Jones, P.D.; Knight, R.W.; Kukla, G.; Plummer, N.; Razuvayev, V.N.; Gallo, K.P.; Lidesay, J.; Charlson, R.J.; Peterson, T.C. A new perspective on recent global warming: assymetric trends of daily maximum and minimum temperature. Bul. Am. Meteorol. Soc. 1993, 74, 11007-1023. doi.org/10.1175/1520-0477(1993)074<1007:ANPORG>2.0.CO;2 
4. Kozłowska-Szczęsna T.; Błażejczyk K.; Krawczyk B.. Bioklimatologia człowieka. Metody i ich zastosowanie w badaniach bioklimatu Polski. Monografie 1, IGiPZ PAN, Warszawa. 1997.

5. Tomczyk, A.M.; Szyga-Pluta, K.; Majkowska, A. Frost and frost-free periods in Poland and neighboring countries. Open Geosciences (formerly Central European Journal of Geosciences - CEJG) 2015, 7, 812-823. doi: 10.1515/geo-2015-0061

6. Tomczyk, A.M.; Szyga-Pluta, K.; Bednorz, E. Occurrence and synoptic background of strong and very strong frost in spring and autumn in Central Europe. Int. J. Biometeorol. 2020, 64, 59-70. https://doi.org/10.1007/s00484-019-01793-z

7. Fortuniak, K.; Kłysik, K.; Wibig, J. Międzydobowa zmienność temperatury powietrza w Łodzi. Acta Geographica Lodziensia 2004, 89, 35-46.

8. IPCC. Climate Change: The Physical Science Basis. Contribution of Working Group I to the Fifth Assessment. Report of the Intergovernmental Panel in Climate Change; Cambridge University Press: Cambridge, UK, 2013.

9. Kossowska-Cezak, U. Duże zmiany temperatury $z$ dnia na dzień a cyrkulacja atmosferyczna. Przegl. Geofiz. 1987, 32(3), 289-302.

10. Rebetez, M. Changes in daily and nightly day-to-day temperature variability during the twentieth century for two stations in Switzerland. Theor. Appl. Climatol. 2001, 69, 13-21. https://doi.org/10.1007/s007040170032

11. Panfil, M.; Dragańska, E. Związki korelacyjne między wskaźnikami NAO wg Jones'a oraz Hurrela a warunkami termicznymi i opadowymi dla Polski północno-wschodniej, Acta Agrophysica 2004, 3(1), 133-142.

12. Panfil, M. Duże zmiany międzydobowe temperatur ekstremalnych w drugiej połowie $\mathrm{XX}$ wieku. Acta Agrophysica, 2007, 10(3), 649-658.

13. Wibig, J.; Głowicki, B. Trends in minimum and maximum temperature in Poland. Clim. Res. 2002, 20, 123-133. doi: $10.3354 / \mathrm{cr} 020123$

14. Porebska M.; Zdunek M. Analysis of extreme temperature events in Central Europe related to high pressure blocking situations in 2001-2011. Meteorol. Z. 2013, 22, 533-540. doi:10.1127/0941-2948/2013/0455

15. Tomczyk, A.M.; Bednorz, E. Heat waves in Central Europe and their circulation conditions. Int. J. Climatol. 2016, 36, 770-782. https://doi.org/10.1002/joc.4381

16. Wibig, J. Heat waves in Poland in the period 1951-2015: Trends, patterns and driving factors. Meteorol. Hydrol. Water Manag. 2018, 6, 37-45. doi:10.26491/mhwm/78420

17. Cattiaux, J.; Douville, H.; Schoetter, R.; Parey, S.; You, P. Projected increase in diurnal and interdiurnal variations of European summer temperatures. Geophys. Res. Lett. 2015, 42, 899907. https://doi.org/10.1002/2014GL062531

18. Lobell, D.B.; Bonfils, C.; Duffy P.B. Climate change uncertainty for daily minimum and maximum temperatures: A model inter-comparison. Geophys. Res. Lett. 2007, 34, L05715. https://doi.org/10.1029/2006GL028726

19. He, B.; Huang, L.; Wang, Q. Precipitation deficits increase high diurnal temperature range extremes. Scientific Reports 2015, 5:12004. https://doi.org/10.1038/srep12004

20. DeGaetano, A.T. A method of infer observation time based on day-to-day temperature $\begin{array}{lllll}\text { variations. } \quad \text { J. Climate } & \text { 1999, 3443-3456. }\end{array}$ https://doi.org/10.1175/1520-0442(1999)012<3443:AMTIOT>2.0.CO;2

21. Wibig, J. Wpływ cyrkulacji atmosferycznej na miedzydobowe zmiany temperatury minimalnej i maksymalnej. Prace i Studia Geogr. 2001, 29, 223-232.

22. Panfil, M. Zmiany i zmienność temperatur ekstremalnych $\mathrm{z}$ dnia na dzień w Polsce północno-wschodniej w okresie 1951-2000. Dok. Geogr. 2006, 32, 225-229.

23. Ciaranek, D. Krókookresowe zmiany maksymalnej temperatury powietrza w półroczu chłodnym w Polsce. Acta Sci. Pol. Formatio Circumiectus 2016, 15(1), 49-58. http://dx.doi.org/10.15576/ASP.FC/2016.15.1.49 
24. Piotrowicz, K.; Ciaranek, D.; Guzik, I. Short-term variations in the air temperature in Krakow (Poland) as an indicator of climate change in Central Europe. Idojaras 2017, 121(2), 117-135.

25. Brunetti, M.; Buffoni, L.; Maugeri, M.; and Nanni, T. Trends of minimum and maximum daily temperatures in Italy from 1865 to 1996. Theor. Appl. Climatol. 2000, 66, 49-60. https://doi.org/10.1007/s007040070032

26. Moberg, A.; Jones, P.D.; Barriendos, M.; Berstoem, H.; Camuffo, D.; Cocheo, C.; Davies, T.D.; Demareae, G.; Maugeri, M.; Martin-Vide, J.; Rodriguez, R.; Verhoeve, T. Day-today-temperature variability trends in 160- to 275-year-long European instrumental records. J Geophys. Res. 2000, 105, 22849-22868.doi:10.1029/2000JD900300

27. Tam, B.Y.; Gough, W.A.; and Mohsin, T. The impact of urbanization and the urban heat island effect on day to day temperature variation. Urban Climate 2015, 12, 1-10. doi: 10.1016/j.uclim.2014.12.004

28. Niedźwiedź, T. Sytuacje synoptyczne I ich wpływ na zróżnicowanie przestrzenne wybranych elementów klimatu w Dorzeczu Górnej Wisły. Rozprawy Habilitacyjne Uniwersytetu Jagiellońskiego 1981, 58, Kraków, Poland.

29. Yarnal, B. Synoptic climatology in Environmental analysis. Belhaven Press, London, UK, 1993.

30. Salmi, T.; Maiittii, A.; Anttila, P.; Ruoho-Airola, T.; Amnel, T. Detecting trends of annual values of atmospheric pollutants by the Mann-Kendall test and Sen's slope estimates-the excel template application MAKESENS, vol. 31. Publications on air quality. Finnish Meteorological Institute, Helsinki, 2002; pp. 1-35

31. James, P.M. An objective classification method for Hess and Berezowsky Grosswetterlagen over Europe. Theor. Appl. Climatol. 2007, 88, 17-42. https://doi.org/10.1007/s00704-006-0239-3

32. Gerstengarbe, F.W.; Werner P.C. Katalog der Großwetterlagen Europas (1881-2004) nach Paul Hess und Helmuth Brezowsky, 6. Auflage, Selbstverlag des Deutschen Wetterdienstes, Offenbach, Potsdam, 2005.

33. Hess, P.; Brezowsky H. Katalog der Grosswetterlagen Europas 1881-1976. 3. Verbesserte und ergänzte Auflage, Berichte des Deutschen Wetterdienstes 1977,15(113).

34. Kossowski, J. Zmienność z dnia na dzień maksymalnej i minimalnej temperatury powietrza. Annales UMCS, 1970, B, 25(6), 206-213.

35. Kuziemska, D. Zróżnicowanie temperatury powietrza na obszarze Polski a typy cyrkulacji atmosferycznej nad Europą Środkową. Przegl. Geofiz. 1987, 32, 277-287.

36. Szwejkowski, Z.; Dragańska, E.; Grabowska, K. Następstwo elementów pogodowych w Polsce północno-wschodniej w latach 1951-2000. Przegląd Naukowy IiKŚ SGGW, 2006. $X V, 1(33), 123-136$.

37. Tomczyk, A.M. Impact of atmospheric circulation on the occurrence of hot nights in Central Europe. Atmosphere 2018, 9, 474. doi:10.3390/atmos9120474 